\section{OPEN ACCESS}

E-ISSN : 2549-6581

Artikel Hasil Penelitian

Diterima : 21 April 2017

Direview : 28 April 2017

Dimuat : Agustus - November 2017
Journal of Issues in Midwifer

\title{
Faktor Yang Berhubungan dengan Pemberian Asi Eksklusif di Desa Randuagung Kecamatan Tajinan Kabupaten Malang
}

\author{
Rismaina Putri ${ }^{1 *}$, Maya Devi Arifiandi ${ }^{2}$, Irvinda ${ }^{1}$, Nikmatun Hasanah ${ }^{1}$, Milasari $^{1}$ \\ ${ }^{1}$ Program Studi S1 Kebidanan Fakultas Kedokteran Universitas Brawijaya, \\ ${ }^{2}$ Program Studi S2 Kebidanan Fakultas Kedokteran Universitas Brawijaya \\ Email*: rismaina_putri@ub.ac.id \\ HP +6281393877654
}

\begin{abstract}
World Health Organization (WHO) recommends mothers to give exclusive breastfeeding to infants for six months. Although breastfeeding has many benefits, the scope of exclusive breastfeeding in Indonesia is still low. Tajinan is the district with the lowest percentage of exclusive breastfeeding in Malang. The aim of this study was to determine the relationship of internal mother factors, husband support, family support and health workers' support with exclusive breastfeeding in the Randugading village. The design of this study was descriptive correlation, using fisher exact test and multiple regression analysis. The samples were selected using purposive sampling and total sampling to 39 mothers. The results showed that there were associations but it wasn't any significant associations between the internal mother factors, including education $p=0.402$, knowledge $p=0992$ and mothers' attitude $p=0.404$ with exclusive breastfeeding in the Randugading village. While there were positive significance associated between husband support $p$ $=0.000$, family support $p=0.000$ and health workers' support $p=0.000$ with exclusive breastfeeding in the Randugading village. The internal mother factors, husband support, family support and health workers' support $p=0.000$ simultaneously had positive significance associated with exclusive breastfeeding in the Randugading village. The determining coefficient was 0,894 which means that correlation was very strong $(0.80-1.00)$. The conclution is there areassociations but itsn't any significant associations between the internal mother factors, including education, knowledge and mothers' attitude with exclusive breastfeeding in the Randugading village. While there are positive significance associate between husband support, family support and health workers' support with exclusive breastfeeding in the Randugading village. The internal mother factors, husband support, family support and health workers' support simultaneously have positive significance associate with exclusive breastfeeding in the Randugading village.
\end{abstract}

Keywords: internal mother factors, husband support, family support, health workers support, exclusive breastfeeding

\footnotetext{
ABSTRAK

World Health Organization (WHO) merekomendasikan pemberian ASI eksklusif pada bayi selama enam bulan. Walaupun ASI memiliki banyak manfaat, tetapi cakupan ASI eksklusif di Indonesia masih rendah. Kecamatan Tajinan merupakan Kecamatan dengan prosentase ASI eksklusif terendah di Kabupaten Malang. Penelitian ini bertujuan untuk mengetahui hubungan faktor internal ibu, dukungan suami, dukungan keluarga dan dukungan petugas kesehatan dengan pemberian asi ekslusif di Desa Randugading. Desain penelitian ini adalah korelasi deskriptif menggunakan uji fisher dan analisis regresi berganda. Pemilihan sampel menggunakan metode
} 
total sampling dan purposive sampling pada 39 ibu. Hasil penelitian menunjukkan terdapat hubungan, namun tidak signifikan antara faktor internal ibu yang meliputi pendidikan $p=0,402$, pengetahuan $p=0.992$ dan sikap ibu $p=0,404$ dengan pemberian ASI eksklusif di desa Randugading. Sedangkan terdapat hubungan positif signifikan antara dukungan suami $p=0,000$, dukungan keluarga $p=0,000$ dan dukungan petugas kesehatan $p=0,000$ dengan pemberian ASI eksklusif di desa Randugading. Faktor internal ibu, dukungan suami, dukungan keluarga dan dukungan petugas kesehatan $p=0,000$ secara simultan berhubungan positif signifikan dengan pemberian ASI eksklusif. Besarnya nilai koefisien determinasi sebesar 0,894 yang berarti bahwa korelasi sangat kuat $(0,80-1,00)$. Kesimpulan dari penelitian ini adalah terdapat hubungan namun tidak signifikan antara faktor internal ibu yang meliputi pendidikan, pengetahuan dan sikap ibu dengan pemberian ASI eksklusif di Desa Randugading, sedangkan dukungan suami, dukungan keluarga dan dukungan petugas kesehatan berhubungan positif signifikan dengan pemberian ASI eksklusif di Desa Randugading. Faktor internal ibu, dukungan suami, dukungan keluarga dan dukungan petugas kesehatan secara simultan berhubungan positif signifikan dengan pemberian ASI eksklusif di Desa Randugading.

Kata kunci: faktor internal ibu, dukungan suami, dukungan keluarga, dukungan petugas kesehatan, pemberian ASI eksklusif

Korespondensi: Rismaina Putri. Surel: rismaina_putri@ub.ac.id

\section{PENDAHULUAN}

Dalam rangka menurunkan angka morbiditas dan mortalitas anak, United Nations Children's Funds (UNICEF) dan World Health Organization (WHO) merekomendasikan sebaiknya anak hanya diberi Air Susu lbu (ASI) saja selama paling sedikit 6 bulan. Pada tahun 2003, Pemerintah Indonesia mengubah rekomendasi lamanya pemberian ASI eksklusif dari 4 bulan menjadi 6 bulan. ASI eksklusif dianjurkan pada beberapa bulan pertama kehidupan karena ASI tidak terkontaminasi dan mengandung banyak gizi yang diperlukan anak pada umur tersebut ${ }^{1}$.

Keputusan Menteri Kesehatan Nomor 450/MENKES/SK/VI/2004 tentang Pemberian ASI Secara Eksklusif di Indonesia menetapkan pemberian ASI eksklusif selama 6 bulan dan dianjurkan dilanjutkan sampai dengan anak berusia 2 tahun atau lebih dengan pemberian makanan tambahan yang sesuai dan tenaga kesehatan agar menginformasikan kepada semua ibu yang baru melahirkan untuk memberikan ASI eksklusif dengan mengacu pada 10 langkah keberhasilan menyusui. Selain itu, menurut UU Nomor 36/2009 tentang Kesehatan pasal 128 ayat 2 dan 3 disebutkan bahwa selama pemberian ASI, pihak keluarga, pemerintah daerah dan masyarakat harus mendukung ibu secara penuh pemberian ASI eksklusif. Berdasarkan Peraturan Pemerintah Republik Indonesia Nomor 33 Tahun 2012 tentang Pemberian ASI Eksklusif pasal 6 yang berbunyi "Setiap ibu yang melahirkan harus memberikan ASI eksklusif kepada bayi yang dilahirkannya"1.

Menurut data Riskesdas 2010, persentase pola menyusui pada bayi umur 0 bulan secara eksklusif adalah $39,8 \%$, 1 bulan $32,5 \%$, 2 bulan $30,7 \%, 3$ bulan $25,2 \%, 4$ bulan $26,3 \%$ dan 5 bulan $15,3 \%$. Persentase tersebut menunjukkan bahwa menyusui secara eksklusif semakin menurun dengan meningkatnya kelompok umur bayi. Dalam rangka mendukung keberhasilan menyusui, sampai tahun 2013 , telah dilatih sebanyak 4.314 orang konselor menyusui dan 415 orang fasilitator pelatihan konseling menyusui ${ }^{1}$.

Hasil Survei Demografi dan Kesehatan Indonesia (SDKI) 2007 menunjukkan cakupan ASI eksklusif bayi 0-6 bulan sebesar $32 \%$ yang menunjukkan kenaikan yang bermakna menjadi $42 \%$ pada tahun 2012. Berdasarkan laporan dinas kesehatan provinsi tahun 2013, sebaran cakupan pemberian ASI eksklusif secara nasional pada bayi 0-6 bulan sebesar $54,3 \%$. Dimana persentase tertinggi terdapat 
pada Provinsi NTB sebesar $79,7 \%$ dan terendah pada Provinsi Maluku yaitu $25,2 \%$. Sedangkan di Jawa Timur sebesar $70,8 \%$ dengan jumlah bayi $0-6$ bulan sebanyak 352.603, yang mendapat ASI eksklusif sebesar 249.643 dan yang tidak mendapat asi eksklusif sebanyak 102.960 bayi ${ }^{1}$.

Pada tahun 2015, cakupan ASI eksklusif di Jawa Timur belum memenuhi target, yaitu $73,8 \%$ sedangkan target nasional $80 \%$. Cakupan ASI eksklusif di Kabupaten Malang juga belum memenuhi target, yaitu sebesar $64,9 \%$. Ada sebanyak 39 puskesmas di Kabupaten Malang, dimana cakupan ASI eksklusif tertinggi di Puskesmas Kromengan yaitu 77,6 \%, sedangkan Puskesmas Tajinan merupakan puskesmas dengan cakupan ASI eksklusif terendah dan jauh dari target yaitu hanya $24,9 \%{ }^{2}$.

Studi pendahuluan pada tanggal 19 Maret 2016 dengan teknik wawancara yang telah dilakukan oleh peneliti kepada 20 ibu di kecamatan Tajinan yang memiliki bayi berumur 0-6 bulan menunjukkan bahwa tingkat pendidikan ibu tergolong rendah, yakni SD dan SMP bahkan ada yang tidak tamat SD. Pengetahuan dan sikap ibu juga tergolong rendah, hampir seluruhnya menyatakan tidak tahu manfaat ASI eksklusif, ibu merasa bayi akan kekurangan nutrisi dan rewel apabila hanya diberi ASI saja sehingga ibu memberi tambahan susu formula, bubur, dan pisang. Ada juga seorang ibu yang mengatakan bahwa pemberian bubur pada bayi yang berumur 4 bulan atas rekomendasi bidannya. Pemberian ASI eksklusif sangat rendah, dari 20 ibu yang diwawancarai, hanya 1 orang yang menyusui secara eksklusif.

\section{METODE PENELITIAN}

\section{Rancangan/Desain Penelitian}

Desain penelitian yang digunakan adalah korelasi deskriptif dengan pendekatan cross sectional.

\section{Sasaran Penelitian}

Sampel yang digunakan adalah total populasi dengan jumlah sebanyak 39 ibu yang memiliki bayi yang berusia 0-6 bulan di Desa Randugading Kecamatan Tajinan pada bulan September-Oktober 2016

\section{Pengembangan Instrumen dan tehnik Pengumpulan Data}

Variabel independen adalah faktor internal ibu, dukungan suami, dukungan keluarga dan dukungan petugas kesehatan yang diukur menggunakan kuesioner, sedangkan variabel dependen adalah pemberian ASI eksklusif di Desa Randugading yang diukur dengan menggunakan kuesioner

\section{Tehnik Analisis Data}

Metode analisis yang digunakan dalam penelitian ini adalah analisis regresi linier berganda dan uji fisher sedangkan uji hipotesisnya menggunakan uji $\mathrm{F}$, uji $\mathrm{t}$, dan koefisien determinasi $\left(R^{2}\right)$. Sebelum dilakukan analisis menggunakan regresi linier berganda, ada beberapa uji asumsi klasik yang harus dipenuhi agar kesimpulan dari regresi tersebut tidak bias, yaitu uji normalitas, uji Multikolinieritas, uji heteroskodesitas, uji Autokorelasi, dan uji Linieritas ${ }^{3}$.

\section{HASIL PENELITIAN \\ Uji Fisher}

Berdasarkan hasil Uji Fisher, pada tabel $2 \times 2$ tidak layak diuji dengan uji chisquare karena ada sel yang nilai expected-nya kurang dari 5 , yaitu sel b. Oleh karena itu, uji yang dipakai adalah uji alternatif yaitu uji Fisher. Pada uji Fisher, nilai signifikansinya adalah 0,402 untuk 2sided (two tail) dan 0,189 untuk 1-sided (one-tail), karena nilai $p>0,05$, maka dapat diambil kesimpulan bahwa tidak ada hubungan yang signifikan antara pendidikan ibu dengan pemberian ASI eklsklusif di Desa Randugading.

\section{Uji Normalitas}

Uji normalitas dilakukan untuk mengetahui apakah data yang diambil dalam penelitian berasal dari populasi yang berdistribusi normal atau tidak. Berdasarkan pengujian kolmogorovsmirnov, di dapatkan $\rho$ value ( Asymp. 
Sig. (2-tailed)) yang bernilai 0.964, dimana nilai tersebut lebih besar daripada $\alpha=0,05$. oleh karena nilai signifikan yang lebih besar daripada $\alpha=0,05$ maka dapat disimpulkan bahwa asumsi normalitas telah terpenuhi sehingga dapat dinyatakan bahwa model regresi tersebut telah layak digunakan.

\section{Uji Multikolinieritas}

Uji Multikolinieritas bertujuan untuk menguji ada tidaknya korelasi antara variabel independent (bebas) dan variabel dependent (terikat) dalam suatu model regresi.Uji Multikolinieritas dalam penelitian ini dilakukan dengan melihat nilai variance inflation factor ( VIF ) dengan menggunakan spss 20.0 dan diperoleh hasil (Lampiran 14) bahwa nilai tolerance pada variabel pengetahuan, sikap ibu, dukungan suami, dukungan keluarga, dan dukungan petugas kesehatan memiliki nilai $>0,1$ dan memiliki nilai VIF $<10$, maka dapat disimpulkan bahwa tidak terjadi Multikolinieritas antar variabel bebas.

\section{Uji heteroskedastisitas}

Uji heteroskedastisitas yang dilakukan untuk menguji apakah dalam suatu model regresi terjadi perbedaan variance dari residual data yang ada.Hasil pengujian

heteroskedastisitas menggunakan histogram dan scatter plot. Persebaran dan jumlah nilai dalam data jawaban responden telah lolos uji heteroskedastisitas, yaitu berupa gambar histogram dimana garis kurva normalnya menyerupai lonceng.Selain itu, hasil uji heteroskedastisitas mengguanakan scatter plot, terlihat titik-titik tersebar baik di atas maupun dibawah angka nol pada sumbu $Y$, secara garis besar, hasil uji heteroskedastisitas menunjukkan bahwa data penelitian memiliki ragam homogeny.

\section{Uji Autokorelasi}

Uji Autokorelasi merupakan pengujian yang dilakukan untuk menguji ada tidaknya pengaruh antara variabel penganggu dalam masing-masing variabel bebas dan di dapatkan hasil penelitian ini tidak terdapat autokorelasi.independen dalam penelitian ini tidak terganggu atau terpengaruhi oleh variabel penggangu.

\section{Uji Linieritas}

Uji Linieritas adalah pengujian yang bertujuan untuk mengetahui apakah regresi bersifat linier atau tidak.Uji Linieritas dalam penelitian ini.Berdasarkan gambar uji Linieritas, dapat dilihat bahwa nilai signifikan tabel ANOVA sebesar 0,000 . Artinya nilai signifikan kurang dari $0,05(0,000<0,05)$ yang berarti bahwa hubungan bersifat linier. Hal ini menunjukan bahwa variabel pengetahuan ibu, sikap ibu, dukungan suami, dukungan keluarga, dan dukungan petugas kesehatan berpola linier dengan pemberian ASI eksklusif.

\section{Uji Regresi Linier Berganda}

Persamaan dari model regresi berganda dalam penelitian ini adalah sebagai berikut :

$Y=1,656+0,000 X_{1}+0,022 X_{2}+0,100 X_{3}$ $+0,132 X_{4}+0,119 X_{5}+e$.

Dari persamaan di atas diinterprestasikan sebagai berikut :

1. $a=566,890$, adalah konstanta yang artinya apabila pengetahuan ibu, sikap ibu, dukungan suami, dukungan keluarga dan dukungan petugas kesehatan $=0$, maka pemberian ASI eksklusif di Desa Randugading sebesar 1,656.

2. Koefisien regresi variabel pengetahuan ibu memiliki nilai positif yaitu sebesar 0,000 . Hal ini berarti apabila terjadi kenaikan pengetahuan ibu sebesar satu satuan maka pemberian ASI eksklusif akan mengalami peningkatan sebesar 0,000 satu satuan.

3. Koefisien regresi variabel sikap ibu memiliki nilai positif yaitu sebesar 0,022 . Hal ini berarti apabila terjadi kenaikan sikap ibu sebesar satu satuan maka pemberian ASI eksklusif akan mengalami peningkatan sebesar 0,022 satu satuan.

4. Koefisien regresi variabel dukungan suami memiliki nilai positif yaitu sebesar 0,100. Hal ini berarti apabila 
terjadi kenaikan dukungan suami ibu sebesar satu satuan maka pemberian ASI eksklusif akan mengalami peningkatan sebesar 0,100 satu satuan.

5. Koefisien regresi variabel dukungan keluarga memiliki nilai positif yaitu sebesar 0,132. Hal ini berarti apabila terjadi kenaikan dukungan keluarga ibu sebesar satu satuan maka pemberian ASI eksklusif akan mengalami peningkatan sebesar 0,132 satu satuan.

6. Koefisien regresi variabel dukungan petugas kesehatan memiliki nilai positif yaitu sebesar 0,119. Hal ini berarti apabila terjadi kenaikan dukungan petugas kesehatan ibu sebesar satu satuan maka pemberian ASI eksklusif akan mengalami peningkatan sebesar 0,119 satu satuan.

\section{Uji Hipotesis}

\section{Uji t ( pengujian parsial)}

Pengujian dilakukan pada tingkat signifikansi 0.05 , nilai df sebesar $\mathrm{n}-\mathrm{k}$ ( $39-2=37$ ) diperoleh nilai $t$ - tabel sebesar 2,026. Berdasarkan hasil uji t, dapat diambil kesimpulan sebagai berikut

1. Berdasarkan hasil uji $t$, diketahui nilai $t$ hitung pengetahuan ibu sebesar 0.011, maka $\mathrm{t}$ - hitung yang yang diperoleh jauh lebih kecil dari nilai $\mathrm{t}$ - tabel $(0.011$ $<2,026$ ), sehingga Ho diterima dan $\mathrm{Ha}$ ditolak. Dengan diterimanya Ho dan ditolaknya $\mathrm{Ha}$, dapat disimpulkan bahwa variabel pengetahuan ibu tidak berhubungan secara signifikan dengan pemberian ASI eksklusif di Desa Randugading.

2. Berdasarkan hasil uji $t$, diketahui nilai $t$ hitung sikap ibu sebesar 0,845, maka t - hitung yang yang diperoleh jauh lebih kecil dari nilai $\mathrm{t}$ - tabel $(0,845<2,026)$, sehingga Ho diterima dan $\mathrm{Ha}$ ditolak. Dengan diterimanya Ho dan ditolaknya Ha, dapat disimpulkan bahwa variabel sikap ibu tidak berhubungan secara signifikan dengan pemberian ASI eksklusif di Desa Randugading.

3. Berdasarkan hasil uji $t$, diketahui nilai $t$ hitung dukungan suami sebesar 3,964, maka $\mathrm{t}$ - hitung yang yang diperoleh jauh lebih besar dari nilai $t$ - tabel $(3,964>2,026)$, sehingga Ho ditolak dan Ha diterima. Dengan ditolaknya Ho dan diterimanya $\mathrm{Ha}$, dapat disimpulkan bahwa variabel dukungan suami berhubungan secara signifikan dengan pemberian ASI eksklusif di Desa Randugading.

4. Berdasarkan hasil uji $t$, diketahui nilai $t$ hitung dukungan keluarga sebesar 5,492 , maka $t$ - hitung yang yang diperoleh jauh lebih besar dari nilai $\mathrm{t}$ tabel $(5,492>2,026)$, sehingga $\mathrm{Ho}$ ditolak dan $\mathrm{Ha}$ diterima. Dengan ditolaknya $\mathrm{Ho}$ dan diterimanya $\mathrm{Ha}$, dapat disimpulkan bahwa variabel dukungan keluarga berhubungan secara signifikan dengan pemberian ASI eksklusif di Desa Randugading.

5. Berdasarkan hasil uji $t$, diketahui nilai $t$ hitung dukungan keluarga sebesar 5.779, maka t - hitung yang yang diperoleh jauh lebih besar dari nilai $\mathrm{t}$ tabel $(5.779>2,026)$, sehingga $\mathrm{Ho}$ ditolak dan $\mathrm{Ha}$ diterima. Dengan ditolaknya $\mathrm{Ho}$ dan diterimanya $\mathrm{Ha}$, dapat disimpulkan bahwa variabel dukungan petugas kesehatan berhubungan secara signifikan dengan pemberian ASI eksklusif di Desa Randugading.

\section{Uji F ( pengujian bersama- sama)}

Berdasarkan hasil uji $\mathrm{F}$, diperoleh F-hitung sebesar 65,150. Adapun nilai Ftabel pada tingkat signifikansi $5 \%$ dan degree of freedom (df) sebesar $k=1$ dan derajat bebas penyebut (df2) sebesar $n-$ $\mathrm{k}(39-2=37)$ adalah sebesar 4,46. Jika nilai ini dibandingkan maka nilai $\mathrm{F}$ - hitung lebih besar dari F- tabel $(65,150>4,46)$, sehingga Ho ditolak dan $\mathrm{Ha}$ diterima. Dengan ditolaknya Ho dan diterimanya $\mathrm{Ha}$, dapat disimpulkan bahwa secara simultan variabel independen (pengetahuan ibu, sikap ibu, dukungan suami, dukungan keluarga dan dukungan petugas kesehatan) memiliki hubungan yang sangat signifikan dengan variabel dependen (pemberian ASI eklsklusif di Desa Randugading). 


\section{Uji Koefisien determinasi $\left(\mathbf{R}^{2}\right)$}

Hasil uji koefisien determinasipada penelitian ini diperoleh nilai sebesar 0,894 yang berarti bahwa besarnya hubungan variabel pengetahuan ibu, sikap ibu, dukungan suami, dukungan keluarga dan dukungan petugas kesehatan dengan pemberian ASI eksklusif adalah sebesar $89,4 \%$, sedangkan sisanya sebesar $10,6 \%$ dipengaruhi oleh faktor lain yang tidak termasuk dalam penelitian ini. Nilai 0,894 menunjukkan bahwa korelasi antara variabel pengetahuan ibu, sikap ibu, dukungan suami, dukungan keluarga dan dukungan petugas kesehatan dengan pemberian ASI eksklusif berada dalam kategori hubungan yang sangat kuat ( $0,80-1,00$ )

\section{PEMBAHASAN}

\section{Hubungan Faktor Internal Ibu dengan Pemberian ASI Eksklusif di Desa Randugading}

Hubungan Pendidikan lbu dengan

Pemberian ASI Eksklusif di

DesaRandugading

Berdasarkan hasil penelitian yang

telah dilakukan, diketahui bahwa mayoritas ibu berpendidikan sedang/cukup, yaitu SMP/SMA. Berdasarkan hasil uji Fisherdiperoleh pvalue sebesar $0,402(p>0,05)$, sehingga hipotesis yang menyatakan pendidikan ibu berhubungan signifikan dengan pemberian ASI eksklusif di Desa Randugading Kecamatan Tajinan Kabupaten Malang dinyatakan ditolak.

Tingkat pendidikan seorang ibu diharapkan mampu memberikan kontribusi terhadap pemberian ASI eksklusif. Pendidikan tinggi di harapkan akan memiliki pengetahuan yang cukup tentang pemberian ASI, sehingga berpengaruh positif terhadap produksi ASI, tingkat pendidikan tertinggi yang ditamatkan oleh ibu mempunyai kemungkinan menyusui ASI eksklusif 6 kali dibandingkan dengan ibu yang tidak sekolah dan tamat SD, walaupun tidak dapat dipisahkan pendidikan formal memiliki potensi lama untuk menyusui bayinya dari pada ibu berpendidikan tinggi ${ }^{4}$.
Penelitian ini tidak sejalan oleh penelitian yang dilakukanmenunjukkan bahwa tingkat pendidikan ibu berhubungan dengan pemberian ASI eksklusif ${ }^{5}$.Penelitian (Nascimento, 2010) menyatakan bahwa rendahnya pendidikan ibu berhubungan dengan gangguan pemberian ASI eksklusif untuk bayi berusia 6 bulan di wilayah selatan Brazill $^{6}$.Selain itu penelitian yang dilakukan oleh (Thu, Eriksson, \& Khanh, 2012) menyatakan bahwa terdapat hubungan antar tingkat pendidikan ibu dengan pemberian $\mathrm{ASI}$ di wilayah pedesaan dan perkotaan Vietnam, semakin tinggi tingkat pendidikan ibu maka semakin lama durasi pemberian ASI.Tingkat pendidikan ibu diharapkan mampu untuk memberikan kontribusi terhadap pemberian ASI eksklusif.Namun dalam penelitian ini terlihat bahwa ibu yang memiliki pendidikan yang sedang justru cenderung tidak memberikan ASI eksklusif pada bayinya disebabkan karena dukungan keluarga yang kurang. Maka penting bagi ibu yang memiliki pendidikan yang sedang dapat mengaplikasikan pengetahuannya dalam pemberian ASI eksklusif karena saat ini banyak cara yang dapat dilakukan ibu untuk memberikan ASI secara eksklusif pada bayinya ${ }^{7}$.

Hubungan Pengetahuan Ibu dengan Pemberian ASI Eksklusif di Desa Randugading

Berdasarkan hasil penelitian yang telah dilakukan, diketahui bahwa mayoritas ibu memiliki pengetahuan baik. Berdasarkan hasil regresi bergandadiperoleh pengetahuan ibu memiliki tingkat signifikansi sebesar 0.992 $(p>0,05)$, nilai koefisien regresi sebesar 0,000 dan nilai t-hitung lebih kecil dari ttabel $(0.011<2,026)$. Berdasarkan hasil tersebut maka hipotesis yang menyatakan pengetahuan ibu berhubungan positif dengan pemberian ASI eksklusif di Desa Randugading Kecamatan Tajinan Kabupaten Malang dinyatakan ditolak.

Hasil penelitian ini menunjukkan bahwa tidak ada hubungan positif yang signifikan antara pengetahuan ibu dengan pemberian ASI eksklusif di Desa 
Randugading Kecamatan Tajinan Kabupaten Malang.Hal ini menunjukkan bahwa meskipun ibu sudah berpengetahuan baik, tidak mempengaruhi ibu untuk tetap memberikan ASI eksklusif kepada bayinya.Penelitian ini didukung oleh penelitian yang dilakukan Mamahit (2011) yang menyatakan tidak ada hubungan antara pengetahuan dengan pemberian ASl eksklusif ${ }^{8}$.

Penelitian ini berbeda dengan penelitian yang dilakukan oleh Shally Barina (2011) menyatakan hubungan yang signifikan antara pengetahuan ibu dengan perilaku pemberian ASI eksklusif karena apabila ibu yang memiliki pengetahuan tentang manfaat ASI eksklusif akan lebih yakin tentang apa yang akan dilakukan dan akibat yang ditimbulkan.

Walaupun tidak ada program penyuluhan tentang ASI eksklusif di posyandu, namun, secara spontan ibu-ibu selalu berinisiatif bertanya tentang ASI eksklusif pada petugas kesehatan pada saat kegiatan posyandu dan sering mendapat informasi dari keluarga atau teman yang berlatar belakang kesehatan. sehingga responden dapat mengisi kuesioner dengan baik dan mayoritas berpengetahuan baik. Pengetahuan tentang ASI eksklusif tidak hanya bisa diperoleh melalui pendidikan formal tetapi bisa melalui informasi dari rekan yang berlatar belakang kesehatan, ataupun dari media massa, karena pengetahuan bukan hanya dari keyakinan atau kepercayaan individu melainkan suatu usaha untuk mencari tahu, atau melalui pengalaman pribadi bersama orang lain.

Menurut asumsi peneliti, pengetahuan baik responden terhadap pemberian ASI eksklusif yang ada di daerah penelitian dipengaruhi inisiatif responden untuk selalu bertukar informasi dengan responden yang lain saat bertemu ditempat arisan, kelompok doa, posyandu, dan mengikuti acara-acara di balai desa. Pada variabel pengetahuan, hanya sekedar tahu saja tidak menjamin perilaku terhadap ASI eksklusif bisa berhasil, walau variabel lain sudah mendukung, namun dukungan dari petugas kesehatan melalui penyuluhan sangat dibutuhkan agar manfaat ASI dapat tersampaikan ke responden, dan manfaat ASI pun dapat dirasakan seperti kesehatan dan tumbuh kembang bayi baik, menghemat biaya ekonomi keluarga, mendukung program SDGs, sehingga dapat menekan angka kesakitan bayi ${ }^{9}$.

Dengan demikian, perlu adanya penyuluhan secara berkala atau melakukan manajemen laktasi selama antenatal, intranatal dan postnatal untuk keberhasilan menyusui secara eksklusif.

\section{Hubungan Sikap Ibu dengan Pemberian} ASI Eksklusif di Desa Randugading

Berdasarkan hasil penelitian yang telah dilakukan, diketahui bahwa mayoritas ibu memiliki sikap mendukung pada pemberian ASI eksklusif. Berdasarkan hasil regresi bergandadiperoleh sikap ibu memiliki tingkat signifikansi sebesar 0,404 $(p>0,05)$, nilai koefisien regresi sebesar 0,022 dan nilai t-hitung lebih kecil dari ttabel $(0,845<2,026)$. Berdasarkan hasil tersebut maka hipotesis yang menyatakan sikap ibu berhubungan positif yang signifikan dengan pemberian ASI eksklusif di Desa Randugading Kecamatan Tajinan Kabupaten Malang dinyatakan ditolak.

Penelitian ini menunjukkan tidak ada hubungan positif yang signifikan antara sikap ibu dengan pemberian ASI eksklusif di Desa Randugading Kecamatan Tajinan Kabupaten Malang.Hasil penelitian ini sesuai dengan penelitian yang dilakukan di La Paz, Bolivia menunjukan bahwa sikap ibu tentang ASI tidak mempengaruhi pola pemberian makan bayi (durasi ASI eksklusif dan pemberian makanan prelaktal atau kolostrum) ${ }^{10}$.

Hubungan Dukungan Suami dengan Pemberian ASI Eksklusif di Desa Randugading

Berdasarkan hasil penelitian yang telah dilakukan, diketahui bahwa mayoritas ibu mendapat dukungan suami pada pemberian ASI eksklusif.Berdasarkan hasil regresi 
bergandadiperoleh dukungan suami memiliki tingkat signifikansi sebesar 0,000 $(p<0,05)$, nilai koefisien regresi sebesar 0,100 dan nilai t-hitung lebih besar dari ttabel $(3,964>2,026)$. Berdasarkan hasil tersebut maka hipotesis yang menyatakan dukungan dukungan suami berhubungan positif yang signifikan dengan pemberian ASI eksklusif di Desa Randugading Kecamatan Tajinan Kabupaten Malang dinyatakan diterima.

Penelitian ini menunjukkan adanya hubungan positif yang signifikan antara dukungan suami dengan pemberian ASI eksklusif di Desa Randugading Kecamatan Tajinan Kabupaten Malang. Hasil penelitian ini sesuai dengan penelitianSetiowati (2011) yang menunjukkan adanya hubungan dukungan suami dengan pemberian ASI eksklusif dengan dukungan suami ( $p$ value 0,021 ) dan menurut penelitian yang dilakukan oleh Ramadani (2010), Ibu yang mendapat dukungan dari suami mempunyai kecenderungan untuk memberikan asi secara eksklusif sebesar 2 kali dibanding ibu yang kurang mendapat dukungan dari suaminya ${ }^{11,12}$.

\section{Hubungan Dukungan Keluarga dengan} Pemberian ASI Eksklusif di Desa Randugading

Berdasarkan hasil penelitian yang telah dilakukan, diketahui bahwa mayoritas ibu mendapat dukungan keluarga pada pemberian ASI eksklusif. Berdasarkan hasil regresi bergandadiperoleh dukungan keluarga memiliki tingkat signifikansi sebesar 0,000 $(p<0,05)$, nilai koefisien regresi sebesar 0,132 dan nilai t-hitung lebih besar dari ttabel $(5,492>2,026)$. Berdasarkan hasil tersebut maka hipotesis yang menyatakan dukungan keluarga berhubungan positif yang signifikan dengan pemberian ASI eksklusif di Desa Randugading Kecamatan Tajinan Kabupaten Malang dinyatakan diterima.

Penelitian ini menunjukkan adanya hubungan positif yang signifikan antara dukungan keluarga dengan pemberian ASI eksklusif. Hasil penelitian ini sesuai dengan penelitian Kriscillia Molly (2014) yang menyatakan ada hubungan dukungan keluarga dengan pemberian ASI eksklusif di kelurahan payolansek payakumbuh barat dengan $p$-value= 0,018 .

Berdasarkan penelitian ini didapat bahwa faktor dukungan keluarga sangat mempengaruhi ibu untuk menyusui bayinya secara eksklusif atau tidak. Ibu yang pasca melahirkan pada hari pertama lebih percaya kepada kebiasaan atau tradisi keluarganya yang sudah dilakukan turun temurun seperti memberikan air gula, memberi makanan tambahan berupa pisang sebelum bayi berumur 6 bulan dengan alasan agar bayi tidak rewel.

Hubungan Dukungan Petugas Kesehatan dengan Pemberian ASI Eksklusif di Desa Randugading

Berdasarkan hasil penelitian yang telah dilakukan, diketahui bahwa mayoritas ibu mendapat dukungan petugas kesehatan pada pemberian ASI eksklusif.Berdasarkan hasil regresi berganda diperoleh dukungan petugas kesehatan memiliki tingkat signifikansi sebesar 0,000 $(p<0,05)$, nilai koefisien regresi sebesar 0,119 dan nilai t-hitung lebih besar dari t-tabel (5.779 > 2,026). Berdasarkan hasil tersebut maka hipotesis yang menyatakan dukungan petugas kesehatan berhubungan positif yang signifikan dengan pemberian ASI eksklusif di Desa Randugading Kecamatan Tajinan Kabupaten Malang dinyatakan diterima.

Penelitian ini menunjukkan adanya hubungan positif yang signifikan antara dukungan petugas kesehatan dengan pemberian ASI eksklusif. Hasil penelitian ini sesuai dengan penelitian Rahmawati A, Burhanuddin Bahar, Abdul Salam yang dilakukan di wilayah kerja puskesmas Bonto Cani Kabupaten Bone dimana hasil penelitiannya bahwa ada hubungan antara peran petugas kesehatan $(p=0,000)$ dengan pemberian ASI Eksklusif di wilayah kerja Puskesmas Bonto Cani Kabupaten Bone. Pada penelitian Isroni (2013) Terdapat hubungan yang signifikan antara peran 
petugas dengan pemberian ASI eksklusif $p \leq 0,05$. Salah satu penyebab dari kurangnya pemberian ASI eksklusif adalah pelayanan yang diberikan di fasilitas kesehatan tidak mendukung pemberian ASI eksklusif ${ }^{13}$.

Walaupun hasil dari pengumpulan data menunjukkan bahwa mayoritas responden mendapat dukungan petugas kesehatan, namun masih ada bidan yang menganjurkan memberikan air gula atau susu formula kepada bayi apabila saat setelah melahirkan air susu ibu tidak keluar, maka perlu adanya pembinaan dan sanksi yang tegas terhadap bidan yang menganjurkan pemberian air gula atau susu formula pada bayi yang baru lahir.

Informasi tentang ASI eksklusif dari petugas kesehatan memiliki kontribusi terhadap pemberian ASI eksklusif, maka penting untuk melakukan penyuluhan dan pemberian informasi pada ibu tentang manajemen laktasi, karena salah satu sebab ibu memberikan susu formula pada 3 hari pertama setelah melahirkan adalah air susu ibu tidak keluar dengan lancar. Dengan memberikan informasi kepada ibu,tentang manajmen laktasi diharapkan mampu untuk meningkatkan usaha ibu dalam melakukan prosedur laktasi yang benar untuk kelancaran produksi ASInya.

Hubungan Pengetahuan Ibu, Sikap Ibu, Dukungan Suami, Dukungan Keluarga dan Dukungan Petugas Kesehatan dengan Pemberian ASI Eksklusif Di Desa Randugading

Dari hasil pengujian diperoleh nilai F-hitung sebesar 65,150 dan nilai F-tabel sebesar 4,46. Sedangkan signifikansinya sebesar 0,000 . Karena nilai signifikansi lebih kecil dari $0,05(0,000<0,05)$ dan nilai F-hitung lebih besar daripada nilai Ftabel $(65,150>4,46)$, maka hipotesis yang menyatakan pengetahuan ibu, sikap ibu, dukungan suami, dukungan keluarga dan dukungan petugas kesehatan berhubungan positif yang signifikan dengan pemberian asi eksklusif di Desa Randugading Kecamatan Tajinan Kabupaten Malang dinyatakan diterima.
Hasil uji Koefisien determinasi $\left(R^{2}\right)$ pada penelitian ini diperoleh nilai adjusted $\mathrm{R}^{2}$ sebesar 0,894 yang berarti bahwa besarnya hubungan variabel pengetahuan ibu, sikap ibu, dukungan suami, dukungan keluarga dan dukungan petugas kesehatan dengan pemberian asi eksklusif di Desa Randugading Kecamatan Tajinan Kabupaten Malang adalah sebesar $89,4 \%$, sedangkan sisanya sebesar $10,6 \%$ dipengaruhi oleh faktor lain yang tidak termasuk dalam penelitian ini.

Kesimpulan hasil penelitian terhadap 39 ibu yang memiliki bayi yang berusia 06 bulan di Desa Randugading didapatkan bahwa faktor internal ibu yang meliputi pendidikan, pengetahuan dan sikap ibu berhubungan positif namun tidak signifikan, dengan pemberian ASI eksklusif di Desa Randugading, artinya ketiga faktor tersebut turut berkontribusi terhadap pemberian ASI eksklusif di Desa Randugading namun tidak sebesar faktor dukungan lainnya, sedangkan dukungan suami, dukungan keluarga dan dukungan petugas kesehatan berhubungan positif yang signifikan dengan pemberian ASI eksklusif di Desa Randugading. Secara simultan, faktor internal ibu, dukungan keluarga dan dukungan petugas kesehatan berhubungan positif yang signifikan dengan pemberian ASI eksklusif di Desa Randugading.

\section{SIMPULAN}

a. Pengetahuan ibu, sikap ibu, dukungan suami, dukungan keluarga dan dukungan petugas kesehatan berhubungan positif yang signifikan dengan pemberian ASI eksklusif di Desa Randugading.

b. Faktor internal ibu yang meliputi pendidikan berhubungan namun tidak signifikan dengan pemberian ASI eksklusif di Desa Randugading.

c. Faktor internal ibu yang meliputi pengetahuan berhubungan positif namun tidak signifikan dengan pemberian ASI eksklusif di Desa Randugading.

d. Faktor internal ibu yang meliputi sikap ibu berhubungan positif namun tidak 
signifikan dengan pemberian ASI eksklusif di Desa Randugading.

\section{DAFTAR PUSTAKA}

[1] Kementerian Kesehatan RI.2014.Infodatin (Pusat Data Dan Informasi). Jakarta Selatan : Kemenkes.

[2] Dinkes.2015.Profil Kesehatan Kabupaten Malang Tahun 2015. Pemerintah Dinkes Kabupaten Malang

[3] Ghozali, Imam. 2011. Aplikasi Analisis Multivariat Dengan Program IBM SPSS 19 edisi kelima. Semarang : Universitas Diponegoro.

[4] Adwinanti. 2004. Hubungan Praktek Pemberian ASI dengan Pengetahuan Ibu tentang ASI, Kekhawatiran Ibu, Dukungan Keluarga dan Status Gizi Bayi Usia 0-6 Bulan. Tugas Akhir. Tidak diterbitkan, Fakultas Pertanian Bogor.

[5] Tan, Kok Leong.2011. Factors Associated with Exclusive Breastfeeding Among Infants Under Six Months of Age in Peninsular Malaysia. International Breastfeeding Journal.

[6] Nascimento. 2010. Exclusive Breastfeeding In Outhern Brazil: Prevalence And Associated Factors Breastfeeding Med.

[7] Thu, H. N., Eriksson, B., \& Khanh, T. T. 2012, Breastfeeding Practices in Urban and Rural Vietnam. BMC Public Health, 12:964.

[8] Mamahit, 2011. Faktor-Faktor Yang Berhubungan Dengan Pemberian ASI Eksklusif Di Kecamatan Girian Kota Bitung.Tesis Unsrat 2011

[9] Mardiyanti., 2007. Pengaruh karakteristik dan dukungan keluarga terhadap pemberian ASI ekslusif di Tanggerang. Tugas Akhir. jurnal Kesehatan Masyarakat Nasional.

[10] Ludvigsson, J. F. (2003). Breastfeeding in Bolivia information and attitudes. BMC Pediatrics, 3.

[11] Setiowati, Tri. 2011. Hubungan Faktor - Faktor lbu Dengan Pelaksanaan Pemberian Asi
Eksklusif Pada Bayi 6-12 Bulan Didesa Cidadap Wilayah Kerja Puskesmas Pagaden Barat Kabupaten Subang Periode Januari - Juli 2011. Stikes Jenderal A. Yani Cimahi.

[12] Ramadani, $M$ dan hadi, Ella Nurlaela. 2010. Dukungan Suami dalam Pemberian ASI Eksklusif di Wilayah Kerja Puskesmas Air Tawar Kota Padang, Sumatra Barat. Jurnal Kesehatan Masyarakat Nasional

[13] Isroni, Astuti. 2013. Determinan Pemberian Asi Eksklusif Pada lbu Menyusui Jurnal Health Quality Vol. 4 No. 1, Nopember 2013, Hal 1-76 